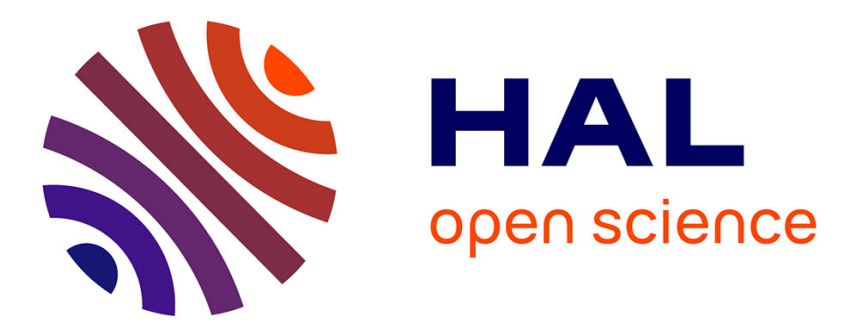

\title{
Management of Invasive Squamous Cell Carcinomas of the Conjunctiva
}

Alexandra Santoni, Juliette Thariat, Célia Maschi, Joel Herault, Stéphanie

Baillif, Sandra Lassalle, Marie Laure Peyrichon, Julia Salleron, Jean-Pierre

Caujolle

\section{To cite this version:}

Alexandra Santoni, Juliette Thariat, Célia Maschi, Joel Herault, Stéphanie Baillif, et al.. Management of Invasive Squamous Cell Carcinomas of the Conjunctiva. American Journal of Ophthalmology, 2019, 200, pp.1 - 9. 10.1016/j.ajo.2018.11.024 . hal-03486675

\section{HAL Id: hal-03486675 \\ https://hal.science/hal-03486675}

Submitted on 20 Dec 2021

HAL is a multi-disciplinary open access archive for the deposit and dissemination of scientific research documents, whether they are published or not. The documents may come from teaching and research institutions in France or abroad, or from public or private research centers.
L'archive ouverte pluridisciplinaire HAL, est destinée au dépôt et à la diffusion de documents scientifiques de niveau recherche, publiés ou non, émanant des établissements d'enseignement et de recherche français ou étrangers, des laboratoires publics ou privés.

\section{(ㄷ)(1) $\$$}

Distributed under a Creative Commons Attribution - NonCommerciall 4.0 International 


\section{TITLE PAGE}

Manuscript title: Management of invasive squamous cell carcinomas of the conjunctiva

Treatment of invasive conjunctival carcinoma

Alexandra SANTONI ${ }^{1}$, Juliette THARIAT ${ }^{2}$, Célia MASCHI ${ }^{1}$, Joel HERAULT ${ }^{3}$, Stéphanie BAILLIF $^{1}$, Sandra LASSALLE ${ }^{5}$, Marie Laure PEYRICHON ${ }^{3}$, Julia SALLERON ${ }^{4}$, JeanPierre CAUJOLLE ${ }^{1}$

${ }^{1}$ : Department of Ophthalmology, Pasteur 2 Teaching Hospital, Nice, France

2: Department of Radiation Oncology, Francois Baclesse Cancer ARCHADE Center, 3 Av General Harris. 14000 Caen, Normandie Universite-Unicaen, France

${ }^{3}$ : Department of Radiation Oncology, Antoine-Lacassagne Cancer Center, Nice, France

${ }^{4}$ : Department of Biostatistics, Institut de Cancérologie de Lorraine, Université de Lorraine, F54500 Vandœuvre-lès-Nancy, France.

${ }^{5}$ : Department of biopathology, Pasteur 2 Teaching Hospital, Nice, France

\section{Footnote}

Corresponding author:

Prof. Juliette Thariat

Department of Radiation Oncology, Centre Baclesse / ARCHADE, 4 rue General Harris. Caen, France

Tel : 33231455050; Fax: 33231455000; Email : jthariat@ gmail.com 


\section{TEXT}

\section{INTRODUCTION}

Ocular surface squamous neoplasia (OSSN) is a spectrum of diseases ranging from dysplasia to invasive squamous cell carcinoma (SCC). SCCs is one of the most common malignant tumors of the ocular surface ${ }^{1,2}$ with an incidence that varies geographically from 0.3 to 35 per million inhabitants ${ }^{3}$. A trend toward increasing incidence has been reported, and it may be due to ultraviolet light exposure and human papilloma virus infection.

The mainstay of treatment is the standard "no touch" surgical technique, which consists of removing the tumor with clear margins without touching the tumor ${ }^{4}$. It may be associated with absolute alcohol corneal epitheliectomy in case of corneal involvement and cryotherapy of the cut conjunctival edge ${ }^{4-6}$. Due to the high recurrence rates of OSSN, varying from 5 to $53 \%$ after surgery ${ }^{7}$, various adjuvant treatments have been used. These include topical ocular treatments and radiotherapy. Adjuvant topical chemotherapy either consists of antimitotic agents, such as mitomycin C (MMC) ${ }^{8-11}$, 5-fluorouracil ${ }^{12,13}$ or interferon alpha-2b ${ }^{14-16}$. Topical drugs have limited penetration depth. Adjuvant ocular surface radiotherapy can be performed using proton therapy ${ }^{17,18}$, brachytherapy ${ }^{19,20}$ or electron beam radiation therapy ${ }^{21}$ for invasive carcinomas.

SCCs can be both sight- and life-threatening. They can spread into intraocular and orbital structures, and occasionally to regional lymph nodes and distant metastases ${ }^{22,23}$. However, it is debated whether minor invasion may influence the prognosis. Such a distinction is made in routine practice in other tumor types. For example, this distinction between microinvasive and in situ breast adenocarcinomas ${ }^{24}$ or between microscopic or macroscopic extracapsular spread in nodes from human-papilloma virus squamous cell carcinomas of the head and neck is taken into account to make for therapeutic decision-making ${ }^{25}$.

Based on the hypothesis that SCCs and microinvasive SCC (miSCC) might have different prognoses, we conducted a study to evaluate recurrence rates in patients with miSCC and SCC referred to a tertiary-care institution.

\section{METHODS}

\section{Study population}

This single-tertiary care (University hospital of Nice) center Institutional Review Boardapproved retrospective case series adhered to the tenets of the Declaration of Helsinki. It included medical records of consecutive patients with histology-proven miSCC/SCC treated surgically at the Department of Ophthalmology from 2002 to 2017, were reviewed.

\section{Data collection}

Clinical data included age, gender, ethnicity, laterality, symptoms and previous history of OSSN. Tumor characteristics (Fig. 1top,down) included: conjunctival location (bulbar conjunctiva with or without involvement of the limbus, tarsal conjunctiva or caruncle), extent into adjacent tissues (corneal and/or scleral involvement, anterior chamber and/or orbital extension), conjunctival location in quadrants (nasal, temporal, superior or inferior), tumor size on physical examination in degrees (less than $90^{\circ}$, between $90^{\circ}$ and $180^{\circ}$ or more than $180^{\circ}$ of corresponding limbal circumference) and maximum thickness measured by optical coherence tomography or ultrasound biomicroscopy. Tumors were staged based on clinical presentation according to the American Joint Committee on Cancer (AJCC) Cancer Staging Manual, $8^{\text {th }}$ Edition (Amin et al. 2017). Histological analysis was made by a senior ocular oncology pathologist. Marker silk sutures on excised tissues indicated excised tissue orientation. Several serial cutting lengths of paraffin-embedded tissue were analyzed perpendicular to the major tissue axis in order to analyze the epithelium and substantia propria on the whole excised tissue. Microinvasion (miSCC) was defined as a focal invasion of less than $0.2 \mathrm{~mm}$ of the substantia propria while invasion $\geq 0.2 \mathrm{~mm}$ was defined SCC (Fig 2). 
Above that depth, the penetration depth of mitomycin can be expected to be more hazardous. Previous history of OSSN lesions before miSCC/SCC were recorded.

Therapeutic modalities, quality of resection, conjunctival reconstruction (conjunctival autograft, amniotic membrane graft and mucous membrane graft) and complications were recorded. An ocular oncologist performed the no-touch technique, associated with corneal epitheliectomy in case of clinical corneal involvement. Cryotherapy of the excision margins was performed at the discretion of the surgeon. Proton therapy was performed in case of SCC at a total dose of 45 grays (Gy, physical dose) in eight fractions, but not in miSCC.

Well-circumscribed limbal lesions were treated to $45 \mathrm{~Gy}$ in eight fractions on macroscopic tumor with additional $2.5 \mathrm{~mm}$ lateral margins. In case of more diffuse lesions, a two-step treatment was used with a large field including the tumor and corresponding ocular quadrants from limbus to conjunctival folds to $31.2 \mathrm{~Gy}$ and a reduced boost to the macroscopic tumor with additional $2.5 \mathrm{~mm}$ lateral margins for 13.8 additional Gy. Fiducials were used to accurately define tumor extents and corresponding radiation fields. A brass collimator shaped the beam laterally in all cases. The beam was modulated using a range filter and a modulation wheel so that the deepest part of the tumor volume be irradiated with 2.5 anteroposterior security margins. An individually shaped compensator was brought into the beam to modify the range of the protons so that the eye was irradiated only at a depth of $2.5 \mathrm{~mm}$ behind the tumor margins and ocular surface. Lid retraction (to spare the palpebra from the radiation field) was performed after 2008 whenever clinically possible.

Postoperative mitomycin was used at a concentration of $0.02 \%$ or $0.04 \%$ depending on quality of the ocular surface. In SCC undergoing proton therapy, 5 patients out of 15 with positive margins had mitomycin (33\%) while none of the 16 patients with negative margins had any $(\mathrm{p}=0.018)$ (for 5 patients, mitomycin was not documented and was considered as missing data). When it was associated with proton therapy, mitomycin was started one month after irradiation to avoid the cumulative acute toxic irritative effects of both irradiation and mitomycin.

A recurrence was defined as the appearance of a new clinical lesion which was not present on immediately postoperative slit lamp photography. Salvage treatments of local relapses were reported.

Statistical analysis

Statistics were performed with the Statistical Analysis System software version 9.4 (SAS Institute Inc., Cary, NC, USA). Qualitative parameters were described as frequency and percentage and quantitative parameters as median and interquartile range. Incidence of local relapse was described by the cumulative incidence function and prognostic factors were investigated by the Fine and Gray model in order to take into account death and metastasis relapse as competing risks. Overall survival was described by Kaplan-Meier method. A pvalue of less than 0.05 was considered statistically significant in the multivariate model.

\section{RESULTS}

Patient and tumor characteristics

Fifty-four patients with a histology-proven diagnosis of miSCC/SCC were included. There were $39 \mathrm{SCC}$ and 15 miSCCs. Mean age at diagnosis was 68.5 years (median, 71 years; interquartile range, 64-79 years). Among them, 3 patients had a history of non-invasive OSSN and 11 had a history of miSCC/SCC before referral to our center ( 3 miSCC and 8 SCC).

Patient, tumor and treatment characteristics are shown in Table 1. Among symptoms, discomfort and itching were the most frequent symptom. Clinical T stage was T1, T2 and T3 in $6(42.9 \%), 2(14.2 \%)$ and $6(42.9 \%)$ of miSCC and $9(23.1 \%), 7(17.9 \%)$, and $23(59.0 \%)$ of SCC ( $\mathrm{p}=0.369)$. There were no T4. All miSCC/SCC were treated surgically using the notouch technique. Surgical margins after surgery at our hospital were negative in $24(51.1 \%)$ of 
the patients. Twenty-five (46.3\%) patients underwent conjunctival reconstruction. Topical mitomycin was used in $14(93.3 \%)$ of the miSCC and $8(20.5 \%)$ of the SCC $(p<0.001$, table 1). Proton therapy was used in $36(92.3 \%)$ of the $39 \mathrm{SCC}$ but none of the $15 \mathrm{miSCC}$ ( $\mathrm{p}<0.001$, table 1). The three SCC patients were not treated with proton therapy because of poor general status.

Side effects of treatments were irritative symptoms such as hyperemia, slight eyelid swelling and superficial punctate keratitis in $20(37.0 \%)$ patients after mitomycin. Radiation-induced complications consisted of cataract in 14 (38.89\%), lid alopecia in 11 (30.6\%), eyelid dermatitis in $5(13.9 \%)$, neovascular glaucoma in $3(8.3 \%)$, cutaneous retraction in $2(5.6 \%)$, lacrimal duct stenosis in $2(5.6 \%)$, retinal vein occlusion in $2(5.6 \%)$ of the patients. One patient had basal cell carcinoma of the inner eyelid 5 years after irradiation.

\section{Outcomes}

There were in 4 local relapses in the 15 miSCC patients and 4 local relapses in the $39 \mathrm{SCC}$ patients. Mean follow-up was 24 months (interquartile range, 15-57 months). The incidence of local relapse at 24 months was $14.8 \%$ (95\% confidence interval [CI], 6.2\%-26.1\%) in the all population with $20 \%$ and $12 \%$ for miSCCs and SCCs, respectively ( $\mathrm{p}=0.079$ ). Median time to local relapse was 11 months (interquartile range, 4.5-18 months). The cumulative incidence of local relapse is shown on figure 3. Of patients undergoing salvage treatment for relapsed miSCC/SCC, 2 had another recurrence. Orbital involvement at relapse was noted in 2 SCC patients.

Regional lymph node metastasis occurred in 4 (7.4\%) patients, within a median time of 41.0 months: two were located in cervical lymph nodes and two in both cervical lymph nodes and the parotid gland. Systemic metastases occurred in two (3.7\%) cases. Liver and bones were both affected in one case, and lungs alone in the other.

At last follow-up, 10 (18.5\%) patients had died. Overall survival was 95.7\% [83.5\%; 98.9\%] at 24 months and $83.4 \%$ [62.7\%;93.2\%] at 60 months. Overall survival is shown on figure 4. Two (3.7\%) deaths were due to a metastatic conjunctival carcinoma and occurred at 21 and 67 months.

\section{Prognostic factors of local relapse}

The prognostic factors of local relapse on univariate analysis are listed in Table 2.

On univariate analysis, only proton therapy was a significant protective factor against local relapse (table 2). Multivariate analysis could not be computed due to a limited number of events ( $\mathrm{N}=8$ local relapses). Cumulative incidence according to proton therapy is shown in figure 5.

Of the three SCC patients who relapsed after trimodal therapy including proton therapy, the relapse occurred in the full dose area. For the third patient, the relapse site could not be repositioned on the proton field (relapse managed at outside institution).

\section{DISCUSSION}

Both miSCC and SCC have a disruption of the basement membrane, which confers a theoretical risk for regional and distant metastases. However, the extent of invasiveness is minimal in miSCC and several institutions have considered it safe to limit adjuvant treatments (and treat miSCC as in situ carcinomas) while others have advocated the same aggressive multimodal strategy as for SCCs. This series represents a unique opportunity to compare the characteristics and outcomes between SCCs and miSCCs. A homogenous practice was used for miSCCs as none of the miSCC patients were advocated adjuvant ocular surface 
irradiation. The assumption was that mitomycin was sufficient to treat the $0.2 \mathrm{~mm}$ of invasion under the basement membrane. While mitomycin can only have a superficial effect, it was used in this series in SCC cases with incomplete microscopic resection where the surgical cut was in contact of some neoplastic cells, i.e. when the no touch technique failed with a subsequent risk for conjunctival tumor graft. In the other SCC, given the no touch technique, mitomycin was not used and proton therapy was performed.

The trend for a higher local recurrence rate of miSCCs compared to SCCs is intriguing but has also been reported by others ${ }^{6}$. In the current series, the characteristics of miSCC and SCC only differed with respect to two therapeutic options, i.e. irradiation by proton therapy and mitomycin: The former was only performed in SCC while the latter was performed in all but one miSCC and only two SCC patients. Prognostic factors on univariate analysis were proton therapy only, which was associated with a lower risk for local relapse. Mitomycin was not associated with a lower risk for local relapse. In contrast to several other studies ${ }^{7,23,26}$, the recurrence rates were rather low (below 20\%) in SCCs using a trimodal therapeutic strategy (surgery, proton therapy, mitomycin). Clinical primary (T) stage was not associated with poorer local relapse rates in this series.

Intriguingly, miSCC had slightly higher crude local relapse rates despite acknowledged as being less aggressive than SCC histologically. As it is the histology itself that made physicians advocate less intensive treatment, histology and treatment cannot be assessed as independent prognostic factors. Surgery and quality of resection, a major endpoint in other series, were similar in miSCC and SCC. The only difference favorable prognostic factor in terms of local relapse was adjuvant irradiation by proton therapy, which was delivered in SCCs only. Whether proton therapy could have improved recurrence rates in miSCCs cannot be ascertained in this study (due to dependence between histology and treatment). However, the treatment of miSCC was less intensive only with respect to proton therapy, as for mitomycin was quite systematically performed in miSCC, which was not the case in SCC. Thus, the observation of a lower elapse rate with irradiation by proton therapy may be considered hypothesis-generating. As relapse rates in SCC (despite 59\% of T3) were slightly better than in miSCC, this observation may also suggest that proton therapy was an important prognostic factor and could have benefited miSCC also. However, this is a retrospective study. Other differences may have been not accounted for here and the overlap between histology and therapy should exert cautious in the interpretation of these results. Although there are few publications on that topic, it should be noted that several teams advocate proton therapy systematically for miSCC in routine practice. Altogether, this change in strategy cannot be taken lightly owing to side effects of ocular surface irradiation. To be practice changing only on this series, one should have confirmatory series from prospective multicentric studies using a methodology to account for attrition biases or, ideally, a randomized study would be necessary.

Series of ocular surface neoplasia (not restricted to miSCC/SCC but also including dysplasia) report an average time to recurrence of 24 months ${ }^{7,26}$. The present series was in accordance with published data with respect to average time to relapse and has a median time to relapse of 11 months after oncological treatment at our institution. Local relapses may be more aggressive and further led to regional metastases (mostly in the parotid/facial and cervical nodal areas) and distant metastases in our series. They were a cause of death in two out of the eight patients who relapsed. Thus, optimal local treatment is critical.

The other risk factors of recurrence included clear resection margins, which in accordance with the literature $7,23,27$. The relatively low rate of local relapse in our series may be due to exclusion of dysplasia and to the systematic no touch surgery. As SCCs may not be so easy to diagnose in routine practice, prior management before referral of atypical conjunctival lesions 
may be best avoided or should follow the no touch surgery rule. In case this technique is not well feasible, patients should be referred to ocular oncology centers first hand if possible ${ }^{23}$.

In the three patients who relapsed after irradiation by proton therapy, two at least relapsed in field, suggesting tumor radioresistance. Whether the dose should have been higher cannot be investigated. Of note, the dose delivered for conjunctival carcinomas is the same as that for conjunctival melanomas, although melanomas are more radioresistant than carcinomas in general. The advantage of proton therapy is comparison to electron therapy is that the dose distribution can be better conformed laterally, i.e. sparing more ocular tissues by avoiding the mushroom shape obtained with electrons.

A third of the patients had complications related with surgery and mitomycin, such as irritative symptoms. Radiation-induced complications due to irradiation of the anterior segment also occurred in a third of the patients but may persist in the long term in contrast to those due to mitomycin. Irradiation of the goblet cells of the conjunctiva can be associated with dry eye syndrome, but this was not a major issue in this series. Field reduction after 31.2 Gy was performed in all cases (or from start in purely limbal lesions). Because most goblet cells are located in the conjunctival folds, field reduction probably helped to limit occurrence of a dry eye syndrome. In contrast, lid alopecia was observed in about a third of the patients. Lid retraction may not be not feasible in case radiation fields need to include the conjunctival folds while palpebral elasticity is insufficient. The proton beam usually included part of the iris and, in non-purely limbal cases, the ciliary body. Rubeosis iridis was not reported in our series. The dose delivered to the iris and ciliary body was lower and more fractionated than what is performed in uveal melanomas (45 Gy in 8 fractions, versus 52 Gy in 4 fractions), which might explain why dilated iris vessels or true rubeosis are more frequent in uveal melanomas treated with proton beams. Secondary glaucoma occurred in three patients. Radiation-induced inflammation may occur following irradiation of these structures. and secondary production of VEGF, which might induce secondary glaucoma.

In most institutions, proton beam is not available, and brachytherapy is a very good complementary method of treating invasive conjunctival SCC. The shape of brachytherapy plaques has to be personalized to the shape of the tumor. Tumors that exhibit limited spread in the mucosal part of the eyelids or include the caruncle, may however be more easily treated with proton therapy. With proton therapy, depth distribution can be modulated using a compensator so that dose is limited behind the eye surface to spare normal tissues. To that extent and given the observed side effects in this series, proton therapy and brachytherapy may be worth being compared to assess the risk benefit ratio of both techniques in conjunctival tumors.

Similar to retrospective studies or early phase trials, this selected population of patients might not be representative of a typical miSCC/SCC population. Another limitation is that this retrospective study suffered from some missing data, such as surgical margin involvement (8\% of missing data). However, conjunctival tissues are fragile and difficult to process for histopathologic evaluation. Thus, biopsy and operative specimens are often quite small and difficult to analyze. Biopsies and operative specimen may be best analyzed in expert ocular oncology tertiary care centers.

To conclude, this study revealed slightly higher relapse rates in miSCCs compared to SCCs. Adjuvant proton therapy might be beneficial regardless of the degree of invasion. Whether this may be attributed to adjuvant irradiation using proton therapy or to histology itself remains to be confirmed with larger multicenter and prospective cohort studies. 
a. Funding/Support: none.

b. Financial Disclosures: no financial disclosures.

c. Other Acknowledgments: none. 


\section{REFERENCES}

1. Nanji AA, Mercado C, Galor A, Dubovy S, Karp CL. Updates in Ocular Surface Tumor Diagnostics. Int Ophthalmol Clin. 2017;57(3):47-62.

2. Shields CL, Demirci H, Karatza E, Shields JA. Clinical survey of 1643 melanocytic and nonmelanocytic conjunctival tumors. Ophthalmology. 2004;111(9):1747-1754.

3. Shields CL, Chien JL, Surakiatchanukul T, Sioufi K, Lally SE, Shields JA. Conjunctival Tumors: Review of Clinical Features, Risks, Biomarkers, and Outcomes--The 2017 J. Donald M. Gass Lecture. Asia Pac J Ophthalmol (Phila). 2017;6(2):109-120.

4. Shields JA, Shields CL, De Potter P. Surgical management of conjunctival tumors. The 1994 Lynn B. McMahan Lecture. Arch Ophthalmol. 1997;115(6):808-815.

5. Peksayar G, Soyturk MK, Demiryont M. Long-term results of cryotherapy on malignant epithelial tumors of the conjunctiva. Am J Ophthalmol. 1989;107(4):337-340.

6. Blasi MA, Maceroni M, Sammarco MG, Pagliara MM. Mitomycin C or interferon as adjuvant therapy to surgery for ocular surface squamous neoplasia: comparative study. Eur J Ophthalmol. 2018;28(2):204-209.

7. Galor A, Karp CL, Oellers $\mathrm{P}$, et al. Predictors of ocular surface squamous neoplasia recurrence after excisional surgery. Ophthalmology. 2012;119(10):1974-1981.

8. Birkholz ES, Goins KM, Sutphin JE, Kitzmann AS, Wagoner MD. Treatment of ocular surface squamous cell intraepithelial neoplasia with and without mitomycin C. Cornea. 2011;30(1):37-41.

9. Hirst LW. Randomized controlled trial of topical mitomycin C for ocular surface squamous neoplasia: early resolution. Ophthalmology. 2007;114(5):976-982.

10. Viani GA, Fendi LI. Adjuvant treatment or primary topical monotherapy for ocular surface squamous neoplasia: a systematic review. Arq Bras Oftalmol. 2017;80(2):131-136.

11. Lee JH, Kim YH, Kim MS, Kim EC. The effect of surgical wide excision and amniotic membrane transplantation with adjuvant topical mitomycin $\mathrm{C}$ treatment in recurrent conjunctival-corneal intraepithelial neoplasia. Semin Ophthalmol. 2014;29(4):192-195.

12. Al-Barrag A, Al-Shaer M, Al-Matary N, Al-Hamdani M. 5-Fluorouracil for the treatment of intraepithelial neoplasia and squamous cell carcinoma of the conjunctiva, and cornea. Clin Ophthalmol. 2010;4:801-808.

13. Parrozzani R, Frizziero L, Trainiti S, et al. Topical $1 \% 5$-fluoruracil as a sole treatment of corneoconjunctival ocular surface squamous neoplasia: long-term study. Br J Ophthalmol. 2017;101(8):1094-1099.

14. Kim HJ, Shields CL, Shah SU, Kaliki S, Lally SE. Giant ocular surface squamous neoplasia managed with interferon alpha-2b as immunotherapy or immunoreduction. Ophthalmology. 2012;119(5):938-944.

15. Shah SU, Kaliki S, Kim HJ, Lally SE, Shields JA, Shields CL. Topical interferon alfa-2b for management of ocular surface squamous neoplasia in 23 cases: outcomes based on American Joint Committee on Cancer classification. Arch Ophthalmol. 2012;130(2):159-164.

16. Shields CL, Kaliki S, Kim HJ, et al. Interferon for ocular surface squamous neoplasia in 81 cases: outcomes based on the American Joint Committee on Cancer classification. Cornea. 2013;32(3):248-256.

17. Caujolle JP, Maschi C, Chauvel P, Herault J, Gastaud P. [Surgery and additional protontherapy for treatment of invasive and recurrent squamous cell carcinomas: technique and preliminary results]. J Fr Ophtalmol. 2009;32(10):707-714.

18. El-Assal KS, Salvi SM, Rundle PA, Mudhar HS, Rennie IG. Treatment of invasive ocular surface squamous neoplasia with proton beam therapy. Eye (Lond). 2013;27(10):1223-1224.

19. Arepalli S, Kaliki S, Shields CL, Emrich J, Komarnicky L, Shields JA. Plaque radiotherapy in the management of scleral-invasive conjunctival squamous cell carcinoma: an analysis of 15 eyes. JAMA Ophthalmol. 2014;132(6):691-696. 
20. Laskar S, Gurram L, Laskar SG, Chaudhari S, Khanna N, Upreti R. Superficial ocular malignancies treated with strontium-90 brachytherapy: long term outcomes. J Contemp Brachytherapy. 2015;7(5):369-373.

21. Graue GF, Tena LB, Finger PT. Electron beam radiation for conjunctival squamous carcinoma. Ophthalmic Plast Reconstr Surg. 2011;27(4):277-281.

22. Cervantes G, Rodriguez AA, Jr., Leal AG. Squamous cell carcinoma of the conjunctiva: clinicopathological features in 287 cases. Can J Ophthalmol. 2002;37(1):14-19; discussion 1920.

23. Yousef YA, Finger PT. Squamous carcinoma and dysplasia of the conjunctiva and cornea: an analysis of 101 cases. Ophthalmology. 2012;119(2):233-240.

24. Rabinovitch RA, Solin $\amalg$, Shank BM, et al. Ductal carcinoma in situ and microinvasive disease. American College of Radiology. ACR Appropriateness Criteria. Radiology. 2000;215 Suppl:1137-1152.

25. Lydiatt WM, Patel SG, O'Sullivan B, et al. Head and Neck cancers-major changes in the American Joint Committee on cancer eighth edition cancer staging manual. CA Cancer J Clin. 2017;67(2):122-137.

26. Miller CV, Wolf A, Klingenstein A, et al. Clinical outcome of advanced squamous cell carcinoma of the conjunctiva. Eye (Lond). 2014;28(8):962-967.

27. Yin VT, Merritt HA, Sniegowski M, Esmaeli B. Eyelid and ocular surface carcinoma: diagnosis and management. Clin Dermatol. 2015;33(2):159-169. 


\section{FIGURE CAPTIONS}

Fig. 1: Photographs of two conjunctival invasive squamous cell carcinoma:

Top. Peribulbar conjunctival squamous cell carcinoma with dilated sentinel vessels.

Down. Voluminous corneal invasion of invasive squamous cell carcinoma.

Figure 2: Invasive squamous cell carcinoma.

Microscopic finding reveals a well differentiated carcinoma. Conjunctival stroma is infiltrated by nests of neoplastic squamous cells. Basal membrane is largely interrupted (HES)

Figure 3: cumulative incidence of local relapse

Figure 4: Overall survival

Figure 5: Incidence of local relapse according to proton therapy (dashed red line represents SCCs and solid blue line miSCCs) 


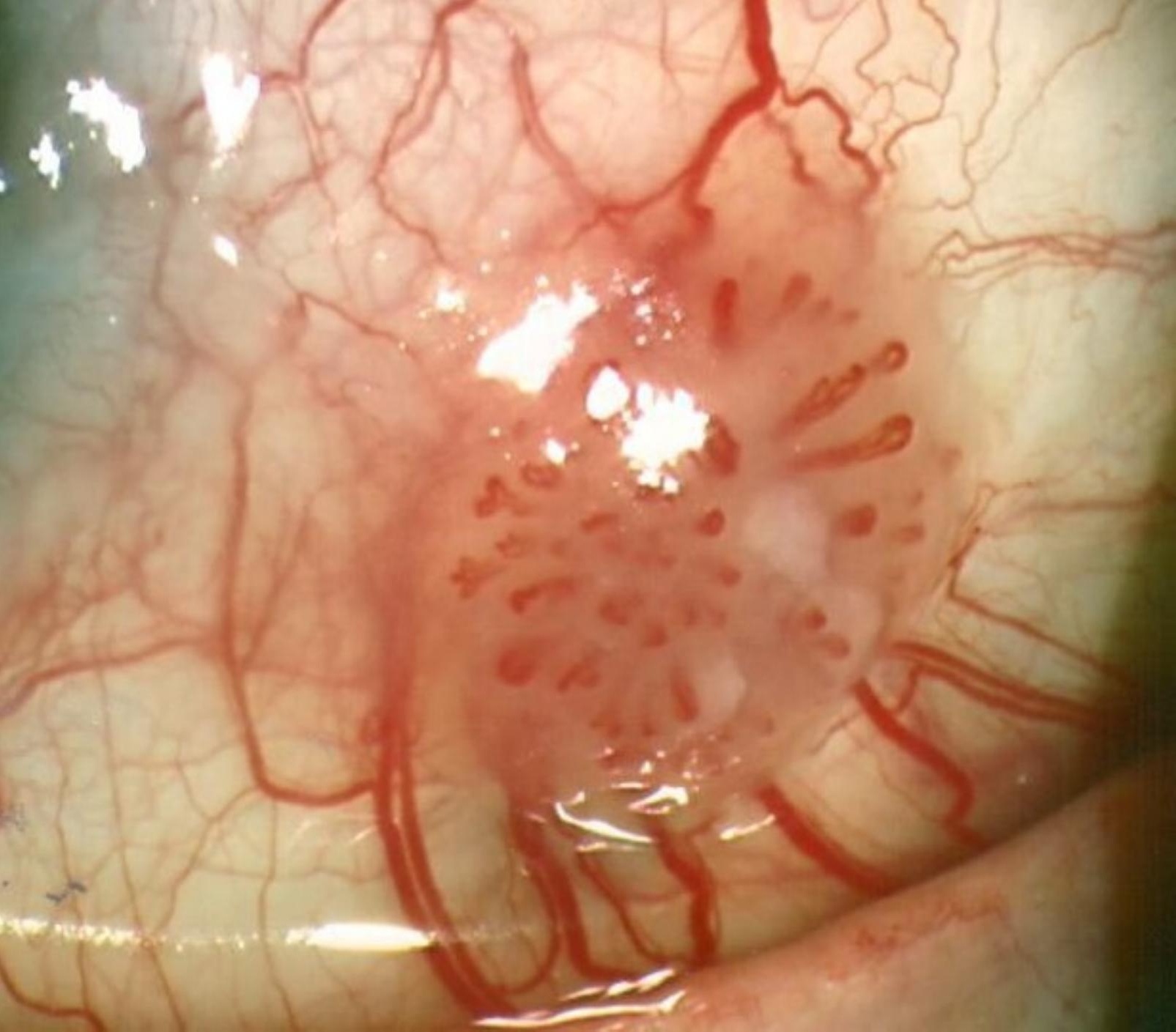




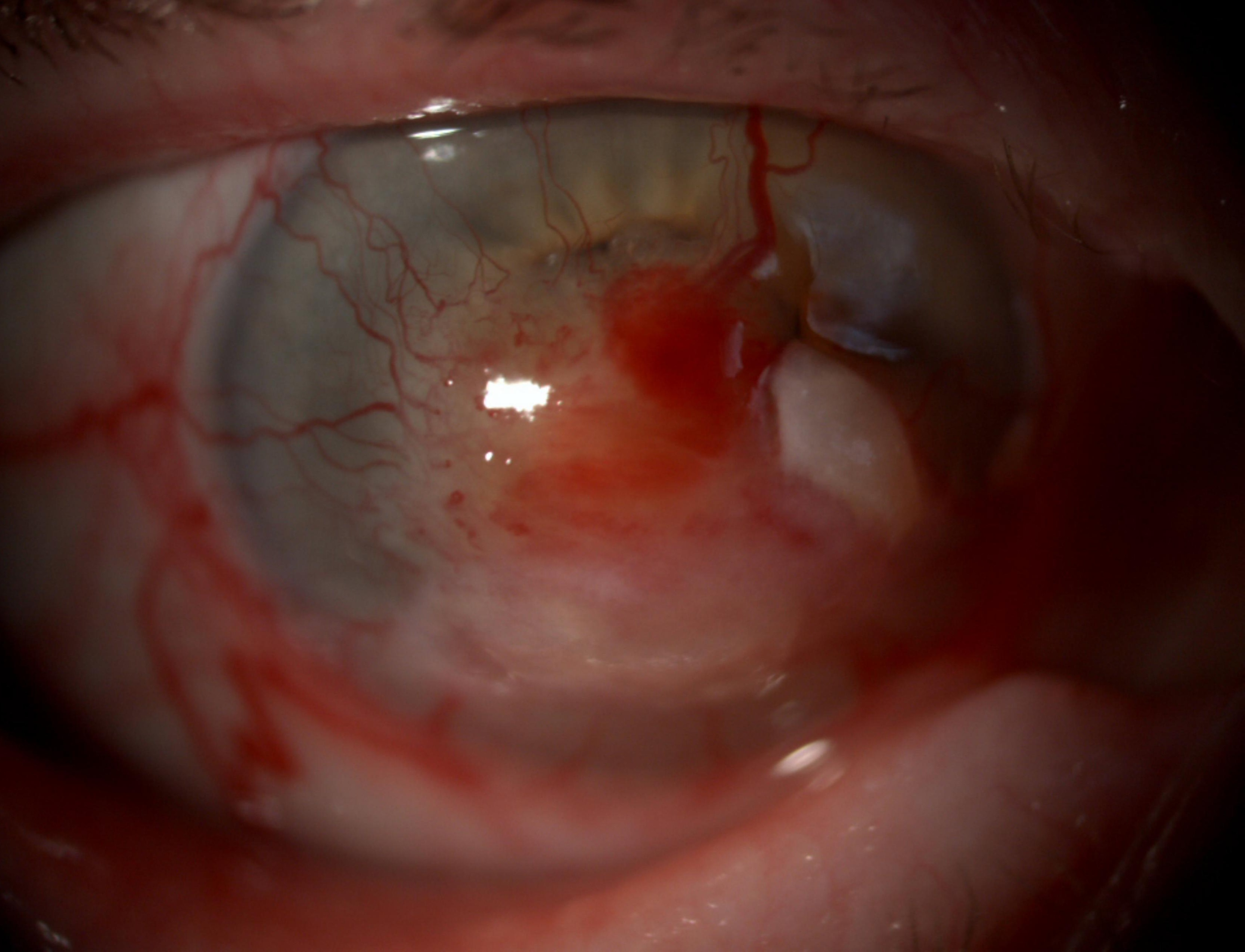




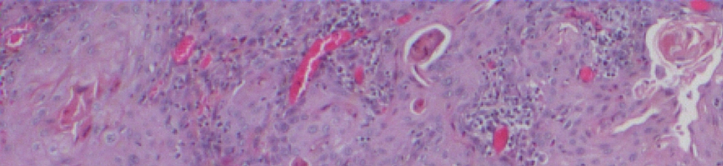

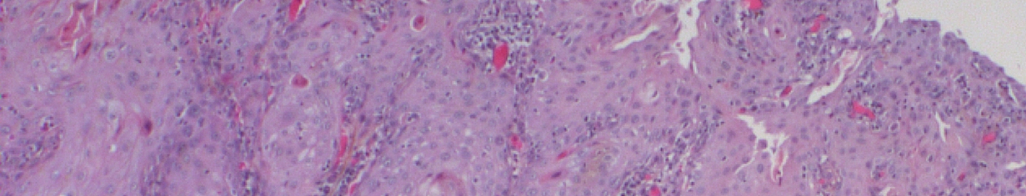

to.

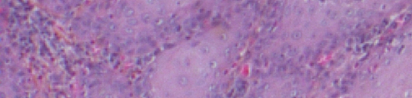

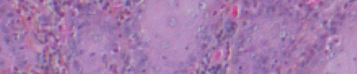

W. a. W.

\section{$6 \lim ^{2}$}

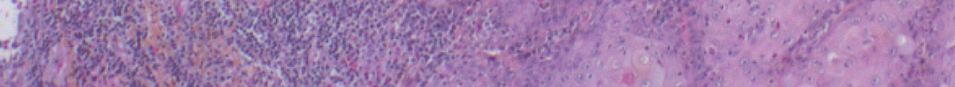

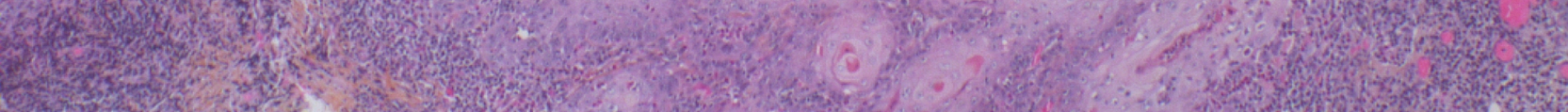
s. 7. 1

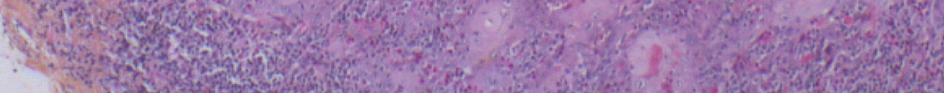

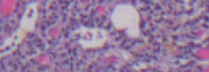

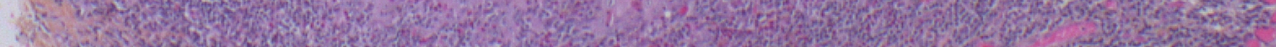

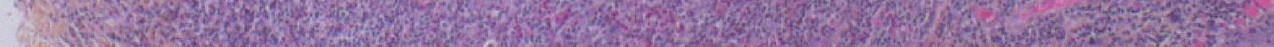




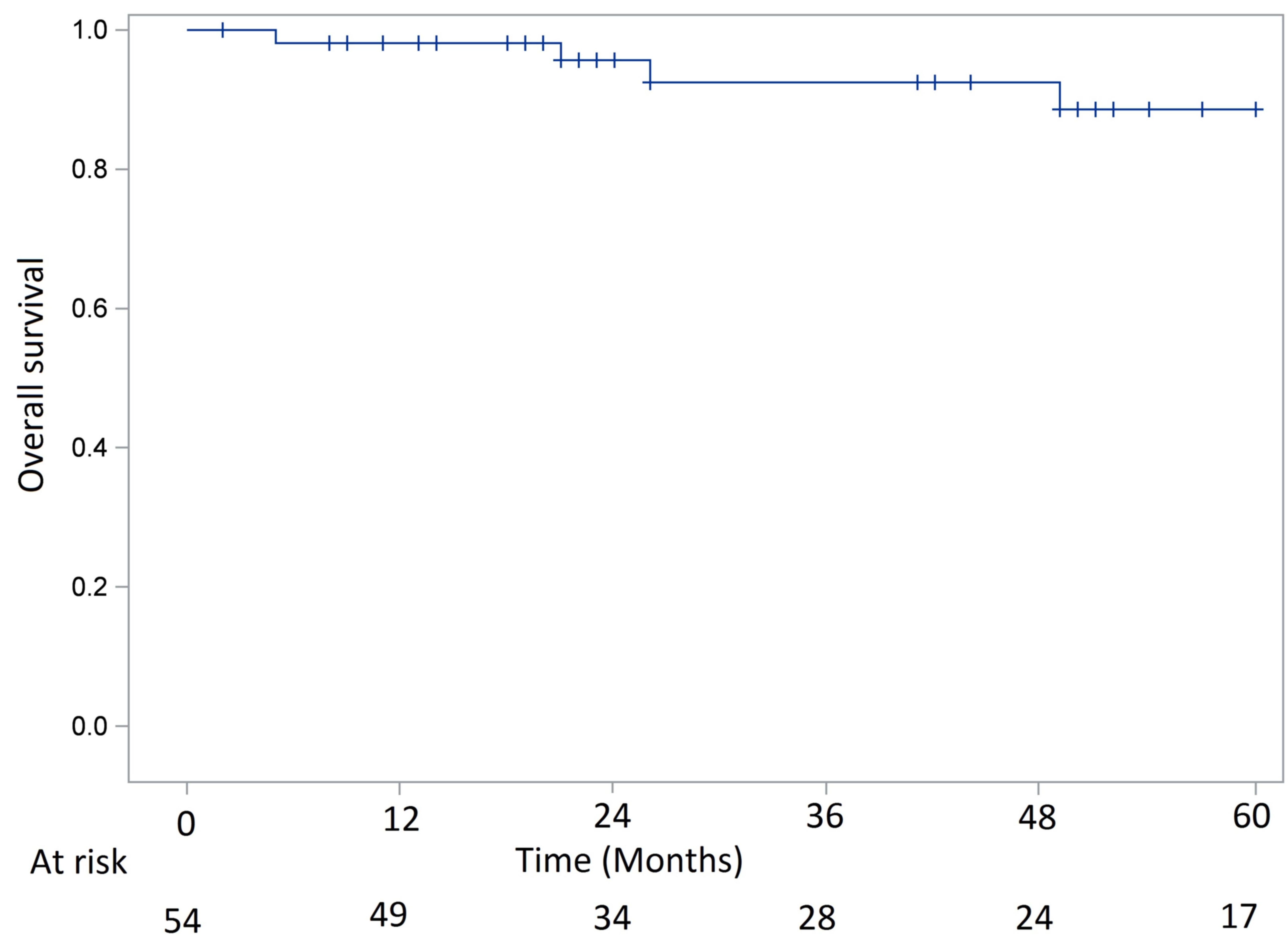




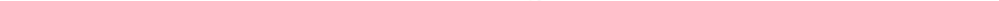




\section{TABLES}

Table 1. Patient, tumor and treatment characteristics of SCC/miSCC

\begin{tabular}{|c|c|c|c|c|}
\hline Analysed factors & $\begin{array}{l}\text { Number of } \\
\text { patients }(\%)\end{array}$ & $\operatorname{miSCC}(\mathrm{N}=15)$ & $\operatorname{SCC}(\mathrm{N}=39)$ & $\mathrm{p}$ value \\
\hline $\begin{array}{l}\text { Age } \\
\text { Less than } 70 \\
\text { More than } 70\end{array}$ & $\begin{array}{l}44.44 \%(24) \\
55.56 \%(30)\end{array}$ & $\begin{array}{l}40 \%(6) \\
60 \%(9)\end{array}$ & $\begin{array}{l}46.15 \%(18) \\
53.85 \%(21)\end{array}$ & 0.684 \\
\hline $\begin{array}{l}\text { Gender }(n=109) \\
\text { Male } \\
\text { Female }\end{array}$ & $\begin{array}{l}69.81 \%(37) \\
30.19 \%(16) \\
\end{array}$ & $\begin{array}{l}78.57 \%(11) \\
21.43 \%(3) \\
\end{array}$ & $\begin{array}{l}66.67 \%(26) \\
33.33 \%(13) \\
\end{array}$ & 0.510 \\
\hline $\begin{array}{l}\text { Medical history } \\
\text { No previous history } \\
\text { Surgery before referral } \\
\text { Treatment before referral at recurrence }\end{array}$ & $\begin{array}{l}37.04 \%(20) \\
37.04 \%(20) \\
25.93 \%(14) \\
\end{array}$ & $\begin{array}{l}53.33 \%(8) \\
20 \%(3) \\
26.67 \%(4) \\
\end{array}$ & $\begin{array}{l}30.77 \%(12) \\
43.59 \%(17) \\
25.64 \%(10) \\
\end{array}$ & 0.210 \\
\hline $\begin{array}{l}\text { Laterality } \\
\text { Right eye } \\
\text { Left eye }\end{array}$ & $\begin{array}{l}48.15 \%(26) \\
51.85 \%(28) \\
\end{array}$ & $\begin{array}{l}33.33 \%(5) \\
66.67 \%(10)\end{array}$ & $\begin{array}{l}53.85 \%(21) \\
46.15 \%(18)\end{array}$ & 0.177 \\
\hline $\begin{array}{l}\text { Symptoms } \\
\text { absent } \\
\text { present }\end{array}$ & $\begin{array}{l}70.37 \%(38) \\
29.63 \%(16)\end{array}$ & $\begin{array}{l}73.33 \%(11) \\
26.67 \%(4)\end{array}$ & $\begin{array}{l}69.23 \%(27) \\
30.77 \%(12) \\
\end{array}$ & 1 \\
\hline $\begin{array}{l}\text { Involved areas } \\
\text { Bulbar conjunctiva wo limbus } \\
\text { Bulbar conjunctiva with limbus } \\
\text { Tarsal conjunctiva or caruncle }\end{array}$ & $\begin{array}{l}12.96 \%(7) \\
70.37 \%(38) \\
16.67 \%(9)\end{array}$ & $\begin{array}{l}13.33 \%(2) \\
73.33 \%(11) \\
13.33 \%(2)\end{array}$ & $\begin{array}{l}12.82 \%(5) \\
69.23 \%(27) \\
17.95 \%(7)\end{array}$ & 0.920 \\
\hline $\begin{array}{l}\text { Extent into adjacent tissues } \\
\text { Corneal involvement } \\
\text { No } \\
\text { Yes } \\
\text { Scleral involvement } \\
\text { No } \\
\text { Yes }\end{array}$ & $\begin{array}{l}57.41 \%(31) \\
42.59 \%(23) \\
72.22 \%(39) \\
27.78 \%(15)\end{array}$ & $\begin{array}{l}60 \%(9) \\
40 \%(6) \\
80 \%(12) \\
20 \%(3) \\
\end{array}$ & $\begin{array}{l}56.41 \%(22) \\
43.59 \%(17) \\
69.23 \%(27) \\
30.77 \%(12)\end{array}$ & $\begin{array}{l}0.811 \\
0.515\end{array}$ \\
\hline $\begin{array}{l}\text { Tumor circumference } \\
\text { Less than } 90^{\circ} \\
\text { More than } 90^{\circ}\end{array}$ & $\begin{array}{l}55.56 \%(30) \\
44.44 \%(24)\end{array}$ & $\begin{array}{l}60 \%(9) \\
40 \%(6)\end{array}$ & $\begin{array}{l}53.85 \%(21) \\
46.15 \%(18) \\
\end{array}$ & 0.684 \\
\hline $\begin{array}{l}\text { Clinical T stage } \\
\text { T1 } \\
\text { T2 } \\
\text { T3 } \\
\text { T4 }\end{array}$ & $\begin{array}{l}29.63 \%(15) \\
16.67 \%(9) \\
53.70 \%(29) \\
0(0)\end{array}$ & $\begin{array}{l}42.86 \%(6) \\
14.29 \%(2) \\
42.86 \%(6) \\
0 \%(0)\end{array}$ & $\begin{array}{l}23.08 \%(9) \\
17.95 \%(7) \\
58.97 \%(23) \\
0(0)\end{array}$ & 0.369 \\
\hline $\begin{array}{l}\text { Surgical margins }(n=47) \\
\text { Negative } \\
\text { Positive }\end{array}$ & $\begin{array}{l}51.06 \%(24) \\
48.94 \%(23)\end{array}$ & $\begin{array}{l}61.54 \%(8) \\
38.46 \%(5)\end{array}$ & $\begin{array}{l}47.06 \%(16) \\
52.94 \%(18)\end{array}$ & 0.374 \\
\hline $\begin{array}{l}\text { Adjuvant treatment } \\
\text { No } \\
\text { Yes }\end{array}$ & $\begin{array}{l}3.7 \%(2) \\
96.3 \%(52)\end{array}$ & $\begin{array}{l}6.67 \%(1) \\
93.33 \%(14)\end{array}$ & $\begin{array}{l}2.56 \%(1) \\
97.44 \%(38)\end{array}$ & 0.482 \\
\hline $\begin{array}{l}\text { Surgery } \\
\text { Surgery without proton } \\
\text { Surgery with proton } \\
\end{array}$ & $\begin{array}{l}33.33 \%(18) \\
66.67 \%(36)\end{array}$ & $\begin{array}{l}100 \%(15) \\
0 \%(0)\end{array}$ & $\begin{array}{l}7.69 \%(3) \\
92.31 \%(36)\end{array}$ & $<0.001$ \\
\hline $\begin{array}{l}\text { Surgery } \\
\text { Surgical resection without graft } \\
\text { Surgical resection with graft } \\
\end{array}$ & $\begin{array}{l}52.83 \%(28) \\
47.17 \%(25)\end{array}$ & $\begin{array}{l}66.67 \%(10) \\
33.33 \%(5) \\
\end{array}$ & $\begin{array}{l}47.37 \%(18) \\
52.63 \%(20)\end{array}$ & 0.205 \\
\hline $\begin{array}{l}\text { Surgery and mitomycin } \\
\text { Surgical resection without mitomycin } \\
\text { Surgical resection and mitomycin } 0.02 \% \\
\text { Surgical resection and mitomycin } 0.04 \%\end{array}$ & $\begin{array}{l}59.26 \%(32) \\
29.63 \%(16) \\
11.11 \%(6)\end{array}$ & $\begin{array}{l}6.67 \%(1) \\
73.33 \%(11) \\
20 \%(3)\end{array}$ & $\begin{array}{l}79.49 \%(31) \\
12.82 \%(5) \\
7.69 \%(3)\end{array}$ & $<0.001$ \\
\hline
\end{tabular}

Abbreviations: AJCC $=$ American Joint Committee on Cancer, $\mathrm{SCC}=$ invasive Squamous Cell Carcinoma, miSCC $=$ microinvasive Squamous Cell Carcinoma 
Table 2: univariate analysis of local relapse

\begin{tabular}{|c|c|c|c|c|c|}
\hline Analysed factors & $\begin{array}{l}\text { Number of } \\
\text { patients (\%) }\end{array}$ & $\begin{array}{l}\text { Number of } \\
\text { events }\end{array}$ & $\begin{array}{l}\text { Cumulative } \\
\text { incidence et } \\
2 \text { years }\end{array}$ & $\mathrm{HR}$ and $95 \% \mathrm{CI}$ & $\begin{array}{l}\mathrm{p}- \\
\text { value }\end{array}$ \\
\hline $\begin{array}{l}\text { Age } \\
\text { Less than } 70 \\
\text { More than } 70\end{array}$ & $\begin{array}{l}44.44 \% \text { (24) } \\
55.56 \%(30)\end{array}$ & $\begin{array}{l}2 \\
6\end{array}$ & $\begin{array}{l}9 \% \\
19 \%\end{array}$ & $\begin{array}{l}1 \\
2.48[0.5 ; 12.2]\end{array}$ & 0.265 \\
\hline $\begin{array}{l}\text { Gender }(n=109) \\
\text { Male } \\
\text { Female }\end{array}$ & $\begin{array}{l}69.81 \%(37) \\
30.19 \%(16)\end{array}$ & $\begin{array}{l}6 \\
2\end{array}$ & $\begin{array}{l}14 \% \\
16 \%\end{array}$ & $\begin{array}{l}1 \\
0.75[0.16 ; 3.49]\end{array}$ & 0.71 \\
\hline $\begin{array}{l}\text { Medical history } \\
\text { No previous history } \\
\text { Surgery before referral } \\
\text { Previous treatment before referral for } \\
\text { relapse }\end{array}$ & $\begin{array}{l}37.04 \%(20) \\
37.04 \%(20) \\
25.93 \%(14)\end{array}$ & $\begin{array}{l}5 \\
1 \\
2\end{array}$ & $\begin{array}{l}29 \% \\
0 \% \\
17 \%\end{array}$ & $\begin{array}{l}1 \\
0.15[0.02 ; 1.09] \\
0.59[0.11 ; 3.02]\end{array}$ & $\begin{array}{l}0.061 \\
0.522\end{array}$ \\
\hline $\begin{array}{l}\text { Surgery } \\
\text { Outside tertiary care center } \\
\text { At tertiary care center }\end{array}$ & $\begin{array}{l}42.59 \%(23) \\
57.41 \%(31)\end{array}$ & $\begin{array}{l}2 \\
6\end{array}$ & $\begin{array}{l}10 \% \\
18 \%\end{array}$ & $\begin{array}{l}1 \\
2.13[0.44 ; 10.34]\end{array}$ & $\begin{array}{l}1 \\
0.351\end{array}$ \\
\hline $\begin{array}{l}\text { Laterality } \\
\text { Right eye } \\
\text { Left eye }\end{array}$ & $\begin{array}{l}48.15 \%(26) \\
51.85 \%(28)\end{array}$ & $\begin{array}{l}2 \\
6 \\
\end{array}$ & $\begin{array}{l}5 \% \\
23 \%\end{array}$ & $\begin{array}{l}1 \\
3.38[0.78 ; 14.56]\end{array}$ & 0.102 \\
\hline $\begin{array}{l}\text { Physical signs or symptoms at diagnosis } \\
\text { Absent } \\
\text { Present }\end{array}$ & $\begin{array}{l}70.37 \%(38) \\
29.63 \%(16) \\
\end{array}$ & $\begin{array}{l}4 \\
4 \\
\end{array}$ & $\begin{array}{l}8 \% \\
29 \%\end{array}$ & $\begin{array}{l}1 \\
2.58[0.68 ; 9.87]\end{array}$ & 0.165 \\
\hline $\begin{array}{l}\text { Initial location } \\
\text { Bulbar conjunctiva without limbus } \\
\text { Bulbar conjunctiva with limbus } \\
\text { Tarsal conjunctiva or caruncle }\end{array}$ & $\begin{array}{l}12.96 \%(7) \\
70.37 \%(38) \\
16.67 \%(9)\end{array}$ & $\begin{array}{l}1 \\
5 \\
2\end{array}$ & $\begin{array}{l}14 \% \\
12 \% \\
24 \%\end{array}$ & $\begin{array}{l}1 \\
0.70[0.08 ; 5.94] \\
1.34[0.11 ; 16.24]\end{array}$ & $\begin{array}{l}0.744 \\
0.819\end{array}$ \\
\hline $\begin{array}{l}\text { Spread into adjacent tissues } \\
\text { Corneal involvement } \\
\text { No } \\
\text { Yes } \\
\text { Scleral involvement } \\
\text { No } \\
\text { Yes }\end{array}$ & $\begin{array}{l}57.41 \%(31) \\
42.59 \%(23) \\
72.22 \%(39) \\
27.78 \%(15)\end{array}$ & $\begin{array}{l}4 \\
4 \\
5 \\
3\end{array}$ & $\begin{array}{l}13 \% \\
17 \% \\
12 \% \\
21 \%\end{array}$ & $\begin{array}{l}1 \\
1.38[0.35 ; 5.41] \\
1 \\
1.42[0.33 ; 6.15]\end{array}$ & 0.649 \\
\hline $\begin{array}{l}\text { Tumor circumference } \\
\text { Less than } 90^{\circ} \\
\text { More than } 90^{\circ}\end{array}$ & $\begin{array}{l}55.56 \%(30) \\
44.44 \%(24)\end{array}$ & $\begin{array}{l}3 \\
5 \\
\end{array}$ & $\begin{array}{l}11 \% \\
20 \%\end{array}$ & $\begin{array}{l}1 \\
2.32[0.55 ; 9.74]\end{array}$ & 0.252 \\
\hline $\begin{array}{l}\text { Squamous cell carcinoma } \\
\text { Microinvasive (miSCC) } \\
\text { Invasive (SCC) }\end{array}$ & $\begin{array}{l}27.78 \%(15) \\
72.22 \%(39) \\
\end{array}$ & $\begin{array}{l}4 \\
4 \\
\end{array}$ & $\begin{array}{l}12 \% \\
20 \%\end{array}$ & $\begin{array}{l}1 \\
3.34[0.87 ; 12.85]\end{array}$ & 0.079 \\
\hline $\begin{array}{l}\text { Tstage } \\
\text { T1 } \\
\text { T2 } \\
\text { T3 }\end{array}$ & $\begin{array}{l}23.08 \%(9) \\
17.95 \%(7) \\
58.97 \%(23)\end{array}$ & $\begin{array}{l}2 \\
1 \\
5\end{array}$ & $\begin{array}{l}13 \% \\
11 \% \\
17 \%\end{array}$ & $\begin{array}{l}1 \\
0.93[0.08 ; 11.25] \\
1.29[0.25 ; 6.76]\end{array}$ & $\begin{array}{l}- \\
0.953 \\
0.758\end{array}$ \\
\hline $\begin{array}{l}\text { Surgical margins }(n=47) \\
\text { Negative } \\
\text { Positive }\end{array}$ & $\begin{array}{l}51.06 \%(24) \\
48.94 \%(23)\end{array}$ & $\begin{array}{l}2 \\
6 \\
\end{array}$ & $\begin{array}{l}10 \% \\
23 \% \\
\end{array}$ & $\begin{array}{l}1 \\
3.42[0.72 ; 16.29]\end{array}$ & 0.123 \\
\hline $\begin{array}{l}\text { Surgery } \\
\text { Surgical resection without protons } \\
\text { Surgical resection with protons }\end{array}$ & $\begin{array}{l}33.33 \%(18) \\
66.67 \%(36)\end{array}$ & $\begin{array}{l}1 \\
7\end{array}$ & $\begin{array}{l}23 \% \\
10 \%\end{array}$ & $\begin{array}{l}1 \\
0.25[0.06 ; 0.97]\end{array}$ & 0.045 \\
\hline $\begin{array}{l}\text { Surgery } \\
\text { Surgical resection without graft } \\
\text { Surgical resection with graft }\end{array}$ & $\begin{array}{l}52.83 \%(28) \\
47.17 \%(25)\end{array}$ & $\begin{array}{l}4 \\
4 \\
\end{array}$ & $\begin{array}{l}15 \% \\
14 \%\end{array}$ & $\begin{array}{l}1 \\
1.1[0.29 ; 4.17]\end{array}$ & 0.894 \\
\hline $\begin{array}{l}\text { Surgery and mitomycin } \\
\text { Surgical resection without mitomycin } \\
\text { Surgical resection and mitomycin }\end{array}$ & $\begin{array}{l}59.26 \%(32) \\
41.74 \%(22)\end{array}$ & $\begin{array}{l}3 \\
5\end{array}$ & $\begin{array}{l}11 \% \\
19 \%\end{array}$ & $\begin{array}{l}1 \\
2.72[0.68 ; 10.88]\end{array}$ & $\begin{array}{l}- \\
0.158\end{array}$ \\
\hline
\end{tabular}

